\begin{abstract}
"They like you to pretend to be something you are not" : An exploration of working
with the intersections of gender, sexuality, 'race', religion and 'refugeeness', through the experience of Lesbian Immigration Support Group (LISG) members and volunteers
\end{abstract}

\title{
Introduction
}

It is painful, I mean when you are saying something you know that you are speaking the truth and somebody is not believing you, you try to give all the evidences and then they are still like not believing you. It is painful, it is really painful, because you don't know how to express yourself again. (Lady Snarewell ${ }^{1}$ )

In this chapter, we explore the lived intersectional experience of gender, sexuality, 'race'2 and religion and other oppressions in the lives of asylum seeking women and discuss the tensions that are produced by the systematic failure of recognising refugee claims on grounds of sexuality as legitimate. We argue that 'refugeeness' troubles these intersections and constructs a subjectivity in particular ways. 'Refugee' is a legal subject position defined by the Geneva Convention (see below). One's legal status as a refugee is only accepted if the asylum claim is successful; thus many refugees are positioned as 'asylum seekers' for many years in legal limbo, where their experiences are shaped by precarity and liminality through policies that prevent them access to work, housing, social welfare and education. Hence, 'refugeeness' is a created subjectivity, determined by a process of becoming, but this subjectivity is never fixed but constantly changing (Lacroix 2004).

\footnotetext{
1 This is a chosen pseudonym by one of the participants of this study (more on this in the methodology section of this chapter).

2 We are using 'race' in inverted commas throughout this chapter to indicate its problematic ontological status and its constructed nature (and in some sense its artificiality). In that sense, we are referring to the 'idea of race' not to 'race' as a category that has some biological validity.
} 
By drawing on our voluntary work and research conducted with the Lesbian Immigration Support Group (LISG) in Manchester, we examine the complexities of the multiple structural oppressions experienced by Black, African and Asian, lesbian asylum seekers and the tensions inherent in supporting them through the British asylum system. We base our analysis on our understanding of intersectionality and its relevance to this particular group.

Intersectionality, a term that was coined by American legal scholar Kimberlé Crenshaw (1989) but evolved through earlier black feminist writing (Nayak 2015, 86), has become a buzzword in feminist scholarship (Davis 2008). Applying black feminist theory to anti-discrimination law, Crenshaw argued that gender and 'race' cannot be separated in black women's lives but that black women are subject to both sexism and racism. The term intersectionality expresses 'the multidimensionality of marginalized subjects' lived experiences' (Crenshaw 1989: 139).

Intersectional thinking has been shaped in particular by black and Chicana lesbian feminists (see, for example, The Combahee River Collective, Tony Cade Bambera; Audre Lorde, Barbara Smith, Cherrie Moraga, Gloria Moreno, Anita Cornwall, Patricia Hill Collins). Audre Lorde showed vividly how intersecting forms of oppression work together and illustrated their psychological impact on black women (Lorde 1984a, 1984b; see also Nayak 2015). Lorde wrote about the damage that is caused by having to neglect and reconcile different parts of her identity as a black lesbian describing how as a black lesbian socialising in predominantly white lesbian environments in New York in the 1950s it was clear that her experiences were different to that of white lesbians (Lorde 1984b). However, the concept of intersectionality is not uncontested. Yuval-Davis (2011:6), for instance, expresses reservations about using the term as she sees it as evoking images of road intersections 'with an indeterminate or contested number of intersecting roads'. She prefers terms and concepts such as 'configuration' (citing Bhavnani 2008), 'social dynamics' (citing Cooper 
2004:12), and 'facets' to describe different aspects for analysis. Nevertheless, Yuval-Davis acknowledges intersectionality can be used as a framework for analysing any social stratification as it recognises that all human beings are 'gendered, classed, ethnised, etc'.

Whilst there is a vast amount of literature on Intersectionality available, only a few studies exist that explicitly interlink intersectionality and asylum (Firth and Maute 2013) and use the concept of Intersectionality for the exploration of the lives of LGBT asylum seekers and refugees (Baillot et al. 2012; Berger 2009; Epstein and Carrillo 2014; Lewis 2014; Morgan 2006). None of these studies include 'refugeeness' in the intersectional experience. Studies on 'refugeeness', on the other hand, do not address sexuality nor intersectionality (Lacroix, 2004), with exceptions (Lee and Brotman, 2011). This chapter aims to address this gap by examining LISG members' positions in a complex web of the social stratifications of gender, sexuality, ethnicity, religion, age, and being an asylum seeker/refugee. As we will show, this position is complex, in particular, because of the predicament women find themselves in, of not only being unrecognised as refugees but also as lesbians, whilst in their country of origin being recognised as a lesbian meant being persecuted, or potentially persecuted.

Before we discuss these experiences and the challenges implied in sexuality based asylum claims, we provide some background to LISG and to this study.

\section{Background and methodology}

LISG grew out of a Manchester based anti-deportation campaign for a lesbian asylum seeker in 2007 . During the campaign, other lesbian asylum seekers contacted the women involved in the campaign seeking support. The campaign group, mainly white women at this point, recognised there was a need for support for lesbian and bisexual women asylum seekers and refugees and so decided to create a support group. One of the authors of this 
article (Karen McCarthy) was a founding member (and the other author, Nina Held joined in 2009). The group currently consists of more than 20 active members, and nine volunteers, two of whom are refugee women. Over 60 members have passed through the group since 2007 and new women are joining regularly. About a half of the members of the group have been granted their status, but of these many have spent years in the limbo of the asylum process, with only three being granted refugee status at first application. Women come from a diverse range of countries including Pakistan, Jamaica, Cameroon, Nigeria, Trinidad and Tobago, Afghanistan, Uganda, Saudi Arabia, Kenya, and South Africa. The group offers emotional, social and practical support, meeting monthly at a local women's centre, where the group have lunch together, talk about cases and events and any other urgent business; also by attending social events and conferences together and sometimes visiting women in hospital. Practical support for members includes: accompanying women to the UKVI in Croydon/South London ${ }^{3}$ to claim asylum; writing support letters; acting as witnesses in court hearings; accompanying women to solicitor appointments, substantive interviews (up to two hours away in Liverpool), and regular signing at the Salford Home Office Reporting Centre.

This chapter draws on our experience of working and conducting research with LISG, focussing on two group discussions that we facilitated in June and October 2016 and drawing on eight semi-structured interviews conducted by Karen McCarthy in 2014/ 2015 as part of her MA dissertation. ${ }^{4}$ Participants were invited to take part in the first discussion and were given an information sheet about its purpose and the aims of the research. Eight women participated, six of whom were asylum seekers, and two were refugees, from various

\footnotetext{
${ }^{3}$ The borough of Croydon is the southernmost borough of London. The journey from Manchester can take at least half a day, involving many changes, and may even necessitate an overnight stay.

${ }^{4}$ The research for Karen McCarthy's MA dissertation was carried out through semi structured interviews with eight members and one 1 volunteer from LISG between December 2014 and February 2015. The dissertation was submitted in March 2015. The transcribed interviews were analysed using Interpretive Phenomenological Analysis (IPA) which allowed for in depth analysis of what participants had said. Apart from two of the participants in the discussion group facilitated for this chapter all other participants were different LISG members. The focus of the small number of semi-structured interviews carried out was a good match for analysis using IPA. As Smith $(2009,143)$ explains, "IPA is particularly suited to researching sex and sexuality in that it can challenge understandings which are based around 'othering' people.
} 
African, Asian and Caribbean countries. The need to protect the women's identities, due to the sensitivity of their cases, means that we use pseudonyms (mostly chosen by the participants) and do not refer to the country of origin, nor provide any other details about the women in discussion of their cases below.

We used a pre-prepared interview guide to help us focus the discussion on some main topics, while remaining open and flexible to following the flow of the discussion. Although narratives 'can aid the analysis of social locations as intersections because they can account for subjectivity in experiences of class, ethnicity and other registers of inequality' (Fotopoulou 2012 :22), the content of the interviews and focus groups was not in the form of 'narratives', that is they are not chronological descriptions of 'a sequence of events' (Coffey and Atkinson 1996: 55). Instead, the participants moved around their experiences and issues during the discussions relating them to the various questions being asked. This fluidity allowed women to express their intersectional experiences not just in response to the research questions but to each other's contributions too. This was important in avoiding a focus on a single social identifier (such as lesbian) and allowing the women to move in and out of their different lived experiences, including as women, lesbians, black women, asylum seekers and refugees, and other identities, and their experience of various combinations of these. The response to each other's experiences and contributions created a space in which the participants were in relative control of defining themselves and their experiences as 'the synergistic relation between inequalities as grounded in the lived experience of hierarchy' (McKinnon 2013: 1029). This reflected that analysis using intersectionality as a method allows us to see that the sum of the various categories, including sexuality and immigration status, is greater than its parts (see McKinnon 2013 and Crenshaw 1989).

In a second group discussion, where we discussed the first draft of this chapter, we went through quotations we used from the previous discussion and this generated further 
debate, adding to our original analysis. The six women who participated seemed to be more comfortable with the process of the group discussion and more confident to voice their experiences. In particular, they expressed their anger about their treatment by the UKVI. Discussing their experiences within the group seemed to be empowering for the women. Witney remarked, "How lucky we are to be involved in such a book. Unusual to be asked to be involved in a book for intellectuals." Her comment highlights the exclusion women feel from many parts of UK society, including academia, but also the different positions between the women and us as researchers.

The legal, social and economic position asylum seeking lesbians find themselves in, stands in stark contrast to the privileged lives of the white (European) volunteers. Whilst this research is shaped by many differences between the researchers and the participants, our different gendered, racialised, classed and sexualised subjectivities - it is also shaped by power inequalities which are reproduced through the system and through our interactions. ${ }^{5}$ For instance, it has been very clear over the last ten years of LISG that the word of white volunteers (all European nationals) is more respected and valued, indeed more likely to be believed, than that of black volunteers and asylum seekers and refugees by the members of the group as well as the 'authorities'. ${ }^{6}$ In addition, as Witney's remark above demonstrates, our work as academics might be perceived in ways that add to the structural intersections of power. In fact, this reflects something that is quite common: white researchers conducting research on asylum seekers and refugees (so far all the requests LISG has received for members to be involved in research have been from white academics). Even if our main aim is to advocate for and raise awareness of the situation of lesbian and bisexual women claiming asylum in the UK, this research might also contribute

\footnotetext{
${ }^{5}$ There has been quite some debate - often framed in terms of "sameness" and "difference" between the interviewer and the interviewee - among feminist researchers about how 'race' impacts the interview situation (see Bhopal 2000, 2001; Edwards 1990; Egharevba 2001; Johnson-Bailey 1999). However, it is important to note here is that 'racial identity is an incomplete project, forever in a process of becoming' (Nayak 2006: 414) and that it is also (re)produced in the research encounter.

${ }^{6}$ For instance, whose support letter and witness account in court carries weight in court.
} 
to furthering our academic careers and further manifest structural inequalities. The research is shaped by the inevitable power relations between researchers and the researched. We chose the 'data' (interview quotes) that we find most interesting and relevant and are the authors of the finished written product. We tried to counter these power inequalities to some extent by actively involving the women in the process of writing and seeking their feedback. We also decided to use many interview quotations in order for the women's voices to be heard. Nevertheless, we are the producers of the knowledge presented in this chapter, and this knowledge production can only be partial and is dependent on our own situatedness (see Haraway, 1991).

\section{Asylum claims based on sexuality}

Article $1 \mathrm{~A}(2)$ of the 1951 Geneva Convention Relating to the Status of Refugees defines a refugee as a person who

owing to well-founded fear of being persecuted for reasons of race, religion, nationality, membership of a particular social group or political opinion, is outside the country of his nationality and is unable or, owing to such fear, unwilling to avail himself of the protection of that country. ${ }^{7}$

Asylum claimants need to provide evidence of, for example, political activity, ethnicity and so on, and in claims based on sexuality evidence of persecution, or fear of persecution, because of sexuality, or perceived sexuality. Claimants need to prove that they belong to a particular social group; in LISG members' cases that of lesbians. It is only since 1999 that

\footnotetext{
7 The emphasis is ours.
} 
gender and sexual identity have been recognised as grounds to claim asylum in the UK, since then it has been accepted that women and lesbians and gay men can form a 'particular social group' (Shah and Islam v Secretary of State for the Home Department, House of Lords, 2 A.C. 629,1999$)$. For an asylum claim based on sexuality to be successful, the asylum seeker has to prove that s/he is lesbian or gay and needs to show a well-founded fear of persecution. This seems to be difficult as the low percentage of accepted lesbian and gay asylum claims indicates. A report by the UK Lesbian and Gay Immigration Group in London (UKLGIG 2010) found that whilst on average $73 \%$ of all initial asylum claims were refused by the Home Office, from all the LGBT cases they looked this figure was $98-99 \%$ (UKLGIG 2010).

There are currently 73 countries (and 5 entities) in the world ( $40 \%$ of all countries) with legislation in place that criminalizes same-sex consensual acts between adults. In 13 of these countries these acts are punishable by death and in 15 others by imprisonment up to life sentences. 40 of these countries are still using homophobic laws imposed during British colonial rule. ${ }^{8}$ However, the existence of such laws itself is not enough for asylum claims to be successful. Before a ruling by the Supreme Court in $2010^{9}$, the majority of claims were refused by the Home Office and the courts with the 'discretion argument'; i.e. the assumption that the person can go back to their country of origin and live their sexuality discreetly (see UKLGIG 2010). Also at LISG we had many cases where decisions were based on this argument (see Held 2016). With such decisions, the Home Office and the courts affectively forced people back into the closet, and often into heterosexual relationships (Johnson 2011).

The Supreme Court ruling of 2010 challenged this reasoning and made it more difficult for Home Office officials and the courts to argue that claimants can go back and live

\footnotetext{
8 , accessed 09/09/2016.

${ }^{9} \mathrm{HJ}$ (Iran) and HT (Cameroon) v Secretary of State for the Home Department [2010] UKSC 31.
} 
their sexuality in secret, without openly claiming a sexual identity. The ruling has been praised as progressive change (see Spijkerboer and Jansen 2011), and there is some indication of better decision making since July 2010 (see UKLGIG 2013). However, according to this decision, courts are still required to identify how openly the claimant would live his or her sexuality if returned (see Weßels 2013). Added to this, negative decisions on grounds of 'credibility' have increased since the 2011 Supreme Court decision (UKLGIG 2013). The UKLGIG found that while before 2010 the majority of claims they looked at were refused by the Home Office, with the 'discretion argument' (UKLGIG 2010), in the majority of negative decisions made between 2010 and 2013 the claimant was not believed to be gay. (Though that does not mean that it was necessarily believed that the person was gay when the 'relocation argument' was used) (UKLGIG 2013).

Decisions on asylum applications are made using policies developed by the UKVI, the Home Office and the courts where the asylum system is generally viewed through the lens of predominantly white and patriarchal organisational cultures. Intersections of gender, sexuality, 'race', age and religion and the structural oppressions experienced by applicants are not acknowledged in decision-making. Rather, decisions are based on a particular understanding of sexuality, namely one that is 'out and proud' and that seems to represent a stereotypical white male middle class gay identity (see Morgan 2006). ${ }^{10}$ This understanding of sexuality draws on a Western model of sexuality whereby gay identity and homosexual conduct are interchangeable and 'which presumes clarity of boundaries between heterosexual and homosexual identity and requires public expression of private and sexual behaviour.' (Morgan 2006: 151-152). Below, we will show why this understanding of sexuality is often problematic for LGBT asylum seekers.

A large number of LGBT asylum seekers are refused (having exhausted their appeal

\footnotetext{
10 For instance, in his judgement Lorde Hope drew on stereotypical images of gay men going to Kylie concerts and drinking 'exotically coloured cocktails'.
} 
rights) as they cannot prove their sexuality, are then becoming 'undocumented' because of 'not having the necessary documents, especially permission to live and work in a foreign country'. ${ }^{1112}$ This results in destitution, as they no longer receive any aid from the state, other than the offer of a plane ticket back to their country of origin, so they are reliant on charity and friends. The impact of the UK asylum system, of being subject to intersected oppressions which limit their ability to be agents of their own lives and deny their reality, compromises their physical and mental health and exposes them to risk of abuse an exploitation. The very real danger of detention and deportation combine with the challenge to mental health of being disbelieved:

when I was in detention I was, I don't know, I was like start, start crazy, it was very, very hard for me, it was very hard, very, very hard, I don't, sometimes I don't, didn't know where I am, I was like maybe the world the world is finished, so. (Sandra, in interview)

The lack of acknowledgement by the UK asylum system of the intersectional nature of oppression and the cumulative effect of being forced into living a precarious and liminal life (a characteristic of 'refugeeness') has an impact on claimants' mental health. Shidlo and Ahola (2013: 10) list the mental health conditions experienced by asylum seekers and refugees, which they describe as being the result of a 'a life time of cumulative trauma' including 'recurrent depression, dissociative disorders, panic disorder, generalised anxiety disorder, social anxiety, traumatic brain injury and substance abuse.' They go on to explain

\footnotetext{
${ }^{11} \mathrm{http}: / /$ www.oxfordlearnersdictionaries.com

12 Those claiming asylum will usually have citizenship in their country of origin, but until they are granted refugee status in the UK they do not have citizenship documentation here Once they have status a passport will cost them £218 if they have 'limited leave to remain', compared to the $£ 72.00$ for a British citizen or a refugee (with unlimited leave to remain). Asylum seekers are given an Application Registration Card (ARC) (a credit card-sized plastic card issued as an acknowledgement of an Asylum or Article 3 application made to IND), which is a way of keeping track of them, and which they must produce when they 'sign' at the local Home Office Reporting Centre. For some even this gives a sense of security as they have something to show if stopped by the police.
} 
that people who are forced to migrate because of their LGBT identity may also experience post-traumatic stress disorders. The marginalisation of those with mental health conditions is well documented and adds another category of the oppressions that cumulatively make up the experience of a black, lesbian, asylum seeker.

Gaining refugee status does not suddenly relieve these oppressions either. Once women get status they realise that they will never go back home, never see their family, or their mother before she dies, all the layers of loss that come in also affect mental health. Added to this the realisation that having their status because they are believed to have a certain identity, does not solve all their problems and they have to negotiate building a new life in a patriarchal, racist society while managing the mental, and other, health issues developed since they have been in the UK.

\section{Intersections of gender, sexuality, 'race', age and religion in decision making}

believe me, be a lesbian, be a Muslim, be a woman, like you in the fire, fire, just in fire. Nobody can help you. (Razia, in interview)

From all the cases that we have supported over the years, only a small percentage (approx. 5\%) were granted asylum in the first instance. Most of the other cases were refused on grounds of credibility, i.e. where it was not believed that the claimant was lesbian and in a few cases, it was argued that there is not enough proof of the persecution of LGBT people in the claimant's country of origin. This can be in countries where (usually male) homosexuality is not illegal, or where the UKVI country of origin reports ${ }^{13}$ draw on Western gay magazines that say the country is safe for (Western) gay men to travel to, and these

\footnotetext{
${ }^{13}$ Country policy and information notes (previously known as country information and guidance reports) are used by UK Visas and Immigration officials to make decisions in asylum and human rights applications. The notes also give information on asylum seekers' countries of origin. (see https://www.gov.uk/government/collections/country-policy-and-information-notes, access date 01/02/2017).
} 
usually refer to holiday resorts. In addition, the situation of lesbian and bisexual women is often very different in these countries due to gender oppression, and is less likely to be documented.

Reports by the UK Lesbian and Gay Immigration Group (UKLGIG 2010, 2013) have documented that delay in disclosure can negatively affect credibility assessment, not recognising that delay may be due to reasons including fear or ignorance of the system. Three of the women participating in the focus groups had their claims refused because of delays in disclosure. They explained this delay with the fact that they were 'still hiding' (Brown Honey; Favour); were 'scared' of someone finding out about their sexuality (Brown Honey; Kin); or did not know 'that they [LGBT people] have the right here to live in the country' (Favour). ${ }^{14}$

Public expression of sexual behaviour is especially difficult for LGBT asylum seekers, who come from countries where such expression would have caused, forced marriage, homophobic violence and potentially imprisonment, possibly death for the person and sometimes for their family too and therefore 'you do everything in hiding' (Lady Snarewell); 'you have to fool everybody around you' (Witney), 'you have to live life in secret, a life in the closet' (Myself).

The women spoke about the pressures of coming out; 'you HAVE to come out, to prove your sexuality, in the UK, you have to prove your sexuality to certain people in the Home Office' and feeling helpless because they do not know how to prove it when the UKVI do not accept their evidence as these accounts illustrate:

'By the time you prove your sexuality they say that's not enough, they don't believe

\footnotetext{
14 It took Brown Honey four years to come out to somebody (her health worker) and five years to disclose her sexuality to the UKVI; it took Kin three years and Favour seven to eight years. Asylum seekers do not have a choice of location and often they are dispersed to areas where people from their home communities live which makes it difficult for LGBT asylum seekers to be out.
} 
you' (Brown Honey)

'It's painful' (Lady Snarewell)

'Yeah, it's annoying, 'what proof do they want from me?' (Brown Honey)

'They think everything is made up; I've done what I can do, I don't know what I need to do next to prove myself a lesbian'. (Kin)

Some lesbian asylum seekers have experienced extreme trauma, visited on them because of the attitudes of others to their sexuality. All have lost, or given up, a lot to find safety and have invested a great deal in being believed, being seen to be lesbian, not least their personal safety, which could be seriously compromised if they were deported. Not being believed then impacts on the women's experiences in particular ways:

Nina: $\quad$ How does it make you feel if they don't believe you?

Kin: $\quad$ It's like painful, like in my case I don't know how to prove to them.

Hope: $\quad$ Back at home you are feeling very bad because you can't show it ['yeah'], you can't show it that you are a lesbian, you can't do action, you can't do action... but here you are allowed to do action, but how to prove it, because those people, Home Office, everything is 'no', you say this they say 'no, no that's a lie' so they make you to feel crazy.

While, Sandra explained in interview:

you can't imagine, you tell people the truth, you tell people your story. You tell people all, all about you, how you're suffering, about your sexuality. But the thing they can't say to you is you're lying. It's not easy to hear that. 
The statements of the women point to the importance of intersectionality as a (painful) lived experience as well as theoretical resource. It is echoed in Lorde's description: I find I am constantly being encouraged to pluck out some one aspect of myself and present this as the meaningful whole, eclipsing or denying the other parts of self' (Lorde 1984a: 122). In the experience of LISG members the particular lens of the UK asylum system picks out sexuality and focuses on that to the exclusion of both all other facets of themselves and the intersection of the structural oppressions they experience. When the women's life experiences, both in their countries of origin and in the UK, are viewed through a Western, white, often male, heterosexual lens, the intersections of their subjectivity are marginalised and/or ignored. It is useful here to reflect back on Yuval-Davis's (2011:6) scepticism of the term intersectionality and her point that it throws up an image of a road intersection (Crenshaw 1991). As the participants set out on their journey in life, in their countries of origin, their direction was controlled by the intersections of 'race', and we would include here imperial colonialism, gender, sexuality, and sometimes class. The development of their personhood (see Firth and Maute 2013) is affected by the restrictions upon them resulting from these intersections. When as a result of this experience they have to change the direction of their journey they are faced with a whole new arrangement of intersections that include the road works of the UK asylum system intersecting with their ethnicity, sexuality and gender. The women's status as refugees and as human beings is controlled and compromised by the asylum system. Following the diversions and obstacles put in their way they navigate through the complicated intersections, developing their sense of themselves, their rights and their resilience until eventually they reach a destination which may, or may not, be the one they had hoped and planned for. For their destination is controlled by their 'refugeeness', which prohibits them from working, studying beyond basic levels, marrying and of course travelling.

At the beginning of the group discussion we asked the participants to write down 
words on sticky notes to describe themselves and their identity. We gave them a list of identifiers they could choose from (such as 'lesbian', 'asylum seeker'), as well as some blank cards, and many women chose different descriptions than those on the list (such as 'cute' and 'strong woman'). ${ }^{15}$ It is worth noting that only three women chose 'asylum seeker' as an identifier while four chose 'Christian' and four chose 'lesbian', three chose African and three chose mother. However, for the purpose of navigating the roadworks and intersection of the asylum system they have to focus on lesbian, even if this is not a word they would previously have used for themselves, or an aspect of their identity they would have prioritised. Vervliet et al (2014) highlight that "migration policy clearly prioritises the category "refugee" over the other categories in its approach to unaccompanied refugee mothers' and does not acknowledge the impact of the intersection of different 'categories' on the lived experience of those women. The same is true for lesbian asylum seekers, where proving their lesbian sexuality supposedly overrides any other consideration for the UKVI, and where intersecting aspects of their personhood, e.g. being a mother or being married, maybe used to deny their sexuality, without recognising that these aspects may have been forced on them, or been 'chosen' as means of surviving. The problem here is that decision-makers often do not take into account how the expression of sexuality is shaped by the intersections of these other aspects of their lives (Hübner 2016).

In the group discussions, women referred to 'race', religion and age as affecting decision-making. Hope spoke of the intersections of 'race' and sexuality by describing that she thinks she was refused because of racism:

\begin{tabular}{|c|c|c|}
\hline $\begin{array}{l}\text { Lesbian }- \text { x } 4 \\
\text { Asylum seeker -x } 3 \\
\text { African }- \text { x } 3 \\
\text { Mother }- \text { x } 3 \\
\text { Christian - x } 4 \\
\text { Persecuted - x } 2\end{array}$ & $\begin{array}{l}\text { Student- x } 2 \\
\text { Refugee - x } 2 \\
\text { Cute } \\
\text { Great } \\
\text { Born a woman } \\
\text { Partner }\end{array}$ & $\begin{array}{l}\text { Grandmother } \\
\text { Educated } \\
\text { Muslim } \\
\text { Different } \\
\text { Strong woman } \\
\text { Human being }\end{array}$ \\
\hline
\end{tabular}


At that time when they tell me that they don't believe me, I thought maybe the Home Office people are just discriminating. Kind of discrimination. This is what I am, that's nature, so when they are telling me they don't believe me this must be discrimination because of my colour. [G laughs and says 'sometimes it's like that'] Yeah because they are white people, these people must be discriminating.'

Favour thought that she was refused because of her age:

I think my solicitor thinks it's my age, he thinks because of my age, it's an age thing? Because of my age they don't think that I'm lesbian but in this country l've seen so many like me, older women like me, I wonder why they think that... [laughter]

We asked Favour how she felt at an event LISG members and volunteers had attended, that was organised by a local lesbian group and attended by mostly older lesbians. She said that she was thinking 'if the $\mathrm{HO}$ could come and see this. I was happy to see them [the older lesbians there], I have found many like that, like me.'

Giametta's (2014) research suggests that LGBT asylum claims might be even more difficult to prove when the claimants 'confess' their religious beliefs which may be regarded as holding on to 'backward' beliefs, which goes against the Western narratives of temporal progression in LGBT identity development that embraces the freedom of the West. This was expressed by Kin:

'They didn't believe me at all; I told them that I was a Muslim lesbian, and they say they don't believe me, everything, everything. If it's one thing or two things or three 
things that we need to focus, then it's OK but they deny me at all and say we don't believe that'.

However, having a faith was not always an easy path:

So Yarl's Wood ${ }^{16}$ was one big turning point where I really had to fight the right way, you're discriminated in church in the chapel you're not allowed cos you're lesbian. (Blessed, in interview)

At the same time, the claimant faces the pressures of constructing their LGBT identity in a certain way (that is non-religious). Thus, gender, sexuality, religion and 'refugeeness' intersect in complex ways in this subject formation. Morgan (2006: 136), writing about the asylum system in the US, argues that decisions are based on racialised sexual stereotypes and culturally specific norms of sexuality. She identifies that it is not good enough for an asylum applicant simply to be attracted to people of the same sex; the applicant must be "gay enough" for the government to find that they have met their burden of proof'. This seems to be similar in the UK. For instance, Claire Bennett and Felicity Thomas (2013: 2627) argue that it is not only the claimant's sexual narrative that is taken as the basis for the decision-making but also her appearance in the court and whether she conforms to Western stereotypes. The authors conclude from their research:

\footnotetext{
${ }^{16}$ Yarl's Wood Immigration removal centre (commonly referred to as a detention centre) is "a fully contained residential centre housing adult women and adult family groups awaiting immigration clearance" (http://www.yarlswood.co.uk/ ). Various security companies have been awarded the contracts to run it including SERCO and G4S. Issues such as sexual abuse, refusal of health care, e.g. lack of care for those with mental health problems, failure to call an ambulance when a woman was miscarrying) have been well documented, including by Channel 4 . Women who have been detained there refer to it as a prison, a 'concentration centre'. Women who have experienced torture, rape and imprisonment in their countries of origin are included in the detainees, though by the Home Office's own rules they should not be. Some women are incarcerated for months on end. Unlike prisoners with criminal convictions immigration detainees do not know how long they will be detained for. Unfortunately, homophobia travels and many LISG women who have been detailed have experience harassment, threats and exclusion from detainee run church services while in Yarl's Wood.
} 
Clearly, decisions regarding someone's claim to be a lesbian were frequently based on the extent to which they conformed to Western stereotypes. Failure to meet these preconceived ideas often resulted in asylum claims being refused and women's individual credibility being questioned.

In our second group discussion women expressed very strongly their anger about not being acknowledged as lesbians. There was a general agreement that some women are refused because of the way they look; 'but what does a lesbian look like?' (Witney), and that the UKVI expects women to put on stereotypes; 'they like you to put on stereotypes' (Brown Honey); 'they like you to pretend to be somebody you are not' (Myself).

The two women who had recently got refugee status, spoke about the changes they were going through and the relief of not having to 'prove' their sexuality anymore. Witney had gone through years of fighting for being accepted as a lesbian, as she had been refused by the UKVI and several judges, like many other women at LISG (most cases of LISG members have only been won after 3-6 years):

In court I was not believed, it was stress. What can I do? Now I have the freedom of whatever I chose. If I want to dress like a man I can. If I want to dress like a girl I can. No one can say because you want prove.

Both gave a very strong account of how they had felt as an asylum seeker: 'When I was an asylum seeker I was in bondage. I was captive. Something is holding you and want to strangle you to death. You are a walking corpse. The living dead.' (Brown Honey) 'If I express myself it will not bring any gains. You are squashed, it is keeping you down. Whatever you say to yourself it comes back. Maybe it is like being hungry and food is there but you can't 
reach - if you eat it you are pushed back.' (Witney) Brown Honey made the point saying 'only foreigners need to prove themselves'. She was asking the participants of the group discussion how many people they see at Pride? She said that only a fraction of the LGBT population would be at Pride as many British people hide their sexuality, or can choose to express it in different ways

The asylum system asks for membership of a particular social group, as listed in the UN convention, and therefore focuses on fixed social identities. The system requires evidence of sexuality and interprets this as evidence of an 'out' sexuality. Having a relationship, adopting a gay lifestyle including participating in lesbian and gay groups and Gay Prides and visiting the Gay Village, can form part of that proof that is expected to be produced (see Morgan 2006: 147; Bennett and Thomas 2013: 26). However, over the years we have also seen decisions by the UKVI and the courts where case owners and judges have argued that going to the Gay Village is not necessarily proof of being gay as many heterosexual people also socialise in the Gay Village. Recently this has been part of the Home Office case against lesbian asylum seekers from Pakistan and Cameroon. Nevertheless, women are often questioned whether they have been to the Gay Village and to name the bars and clubs they had been to, with any mistakes in names being seeing as evidence of lying It is also often assumed that once LGBT people find 'liberation' and can live an openly gay lifestyle in the UK, they would do so (ignoring that many UK born LGBT people do not choose to live in such a way, despite change in public attitudes and laws). There is an assumption that they would 'immediately' start sexual relationships and if they do not so then this damages their credibility (O'Leary 2008: 90).

In McCarthy's research (2015), participants were clear that their lived sexuality was more about relationships than sexual activity. They mostly expressed hope for building positive futures with families and partners, 'you got to go with your heart and you know, what you feel and it's not about sex, it's about having someone, that you love and care for you' 
(Jane). Some women talked about the difficulties of meeting new girlfriends, "maybe you want a relationship with them and you like them, they like you and then you say 'asylum seekers' and zooooom!!' (Brown Honey) So as well as having the pressure to form a relationship to 'prove' sexuality, let alone out of emotional or physical attraction, there is the obstacle of the negative stereotypes of asylum seekers as somehow being 'trouble' of some sort.

While most of the participants stated they enjoyed being able to be more open about their sexuality, and have opportunities to associate with others of a similar identity, living a 'Western' sexual lifestyle can be difficult for LGBT people who have been persecuted and lor prosecuted in their country of origin. They often experience internalised homophobia and a fear of talking about their sexuality. Women often come from cultures where they have learned not to talk about sexuality in general. In addition, the terms 'gay' or 'lesbian' often do not exist in these countries, where constructions of gender and sexuality might be different and therefore it is difficult for asylum claimants to identify as such when they come to the UK (see Berger 2009; O'Leary 2008). Often words that do exist are derogatory, e.g. 'batygyal' (Jamaica)

As Giametta $(2014,587)$ argues:

British case law has been dismissive of the fact that people claiming asylum on the grounds of their sexual orientation negotiate their sexual and gender identities across cultural constructions of gender liminality and sexual identity that do not match the repertoires of western LGBTI identifications and lifestyles.

\section{Conclusion.}


As this chapter has shown, intersectionality is a useful framework for analysing the lived experiences of lesbian asylum seekers, illustrating the intersections of the structural oppressions of gender, class, religion and 'race'. Black feminist scholars, who developed the concept of intersectionality, were motivated by political activism, to trouble the categories of gender and 'race' and address 'the racialisation of gender and the gendering of race' (Fotopoulou 2012, 20) By talking about and reflecting on their intersectional experience, LISG women point to ways in which the structural oppression lesbian asylum seekers face is different from what other lesbian women experience. They illustrate not only that gender and sexuality are racialized but also these categories are shaped by being an asylum seeker or refugee. ${ }^{17}$ Lesbian asylum claimants face different structural oppressions than other members of the 'LGBT community'. Like other LGBT people, their experiences are shaped by the intersections of sexuality, gender, 'race', class, religion (and other social identifiers) but they experience these intersections in complex ways through the asylum system.

The asylum system not only shapes the experiences and subjectivities of (black BME) LISG members but also those of BME and white) volunteers. While volunteers at LISG work, with members, to raise awareness of the inherent racism, sexism and homophobia of the UK immigration system they are often in the position of 'playing the game' by the rules of that system. For example, writing letters of support and acting as witnesses for members where any social status they may have, e.g. as professionals and academics, is invoked as they know this will carry more weight and make the member's case stronger. ${ }^{18}$ To choose not to use their status, the result of intersections of privilege, in this way would be both to deny LISG members access to their power and to put their asylum cases at unnecessary

\footnotetext{
17 In that respect, they reframe Hull et al.'s (1982) 'All the Women are white, all the blacks are men but some of us are brave' to 'All the gays are white, all the refugees are heterosexual but some of us are brave.'

18 For instance, in one LISG member's court hearing, the judge argued that 'considerable weight should be given' to some of her witnesses who had academic backgrounds, arguing that they are used to evaluating empirical evidence and that it is therefore unlikely that in assessing the claimant's sexuality these witnesses could have been fooled (or 'hoodwinked' as the judge termed it).
} 
risk. Most of the volunteers at LISG are part of, and benefit from, the racist, Eurocentric society that created the UK asylum system, but they also experience the impact of gender oppression and heteronormativity.

The homophobic legislation and structures of many nations that are ex-colonies of the West, particularly the UK, is rooted in the deep-seated racism and patriarchy that underpins Western imperialism. What is clear is that the attitudes of Western imperialism towards the 'other', in relation to gender, sexuality, 'race' etc., and the sense of Western superiority inherent in those attitudes, have leached into the UK asylum system and impact on all asylum seekers, and particularly impact on these 'others', in this case lesbian asylum seekers.

Added to this on arrival in the UK lesbian asylum seekers may find that the homophobic oppression they experienced at home is alive and well, despite equality legislation and the possibility of a 'gay' marriage. (The very term 'gay' marriage illustrates the continued underlying homophobia of UK society.) Such asylum seekers will have moved from being citizens of their home state to being non-citizens in the UK. Here the intersection of a range of oppressions and discriminations include that of the sexist, racist and homophobic UK asylum and immigration system. The asylum system is perpetuating imperial colonialism in the ways in which it defines what a lesbian looks like, and how a lesbian behaves, based on Western stereotypes.

Judgements that will affect the lives of lesbian asylum seekers, indeed may jeopardise their life if they are forced to return to the danger they had fled from, will be based on Western stereotypes of sexuality and gender and underpinned by a 'culture of disbelief'. So, as women who most likely had to conceal their attraction to other women, including any sexual activity and/or relationships, from friends, family and community, whose life has been based on a deep, internalised level of secrecy will be expected to 'come out' in one huge leap and to live a life that includes socialising in gay venues, being in a relationship or at the 
least sexually active, to be 'out and proud'. That asylum seekers have an extremely limited income which inhibits their social life is disregarded.

Hence, women like Brown Honey are not rejected because they are black lesbians but because they are black lesbian asylum seekers. 'Refugeeness' shapes the experience of being a black lesbian in particular ways, letting other women perceive them in a potential discriminatory and stereotypical way (as poor, uneducated, untruthful, 'needy').

Structural intersections affect us all, either in advantageous or oppressive ways. They can be lifelines, rungs on a social ladder, part of our social capital or they can be obstacles that trip us up, weights that weigh us down and make it far more difficult to achieve a fulfilling life. As we have shown, for lesbian asylum seekers these structural oppressions are many and varied as they have moved from one collection of structural oppressions to another where a system has been created that pushes them towards the bottom of the social heap. Their experiences are shaped by something more than 'just' sexuality and 'race' and gender and religion. These categories of structural oppression cannot fully encapsulate the experiences of lesbian asylum seekers as their 'refugeeness' cuts across and troubles them in fundamental ways. 


\section{BIBLIOGRAPHY}

Baillot, H., Cowan, S. and Munro, V.E. (2012): "Hearing the Right Gaps': Enabling and Responding to Disclosures of Sexual Violence within the UK Asylum Process', Social \& Legal Studies 21 (3), pp. 269-296.

Bennett, C. and Thomas, F. (2013) 'Seeking Asylum in the UK: Lesbian Perspectives', Forced Migration Review 42, pp. 25-28.

Berg, L. and Millbank, J. Constructing the Personal Narratives of Lesbian, Gay and Bisexual Asylum Claimants Journal of Refugee Studies 22 (2), pp. $195-223$.

Berger, S. A. (2009) 'Production and Reproduction of Gender and Sexuality in Legal Discourses of Asylum in the United States', Signs 34 (3), pp. 659-685

Coffey, A. and Atkinson, P. (1996) Making Sense of Qualitative Data. London: Sage.

Crenshaw, K. (1991) 'Mapping the margins: Intersectionality, Identity Politics, and Violence against Women of Color.' Stanford Law Review 43 (6), pp.1241-1299.

Crenshaw, K. (1989) 'Demarginalizing the Intersection of Race and Sex: A Black Feminist Critique of Antidiscrimination Doctrine, Feminist Theory, and Antiracist Politics', University of Chicago Legal Forum 14, pp. 538-554.

Davis, K. (2008) 'Intersectionality as Buzzword: A Sociology of Science Perspective on What Makes a Feminist Theory Successful', Feminist Theory 9 (1), pp. 67-85. 
Edwards, R. (1990): "Connecting method and epistemology: a white woman interviewing black women", Women's Studies Int. Forum, 13 (5), pp. 477-490.

Egharevba, I. (2001): "Researching an-'other' minority ethnic community: reflections of a black female researcher on the intersections of race, gender and other power positions on the research process", Int. J. Social Research Methodology, 4 (3), pp. 225-241.

Epstein, S and H. Carrillo (2014) Immigrant sexual citizenship: intersectional templates among Mexican gay immigrants to the USA, Citizenship Studies 18 (3-4), pp. 259-276.

Firth, G. and Mauthe, B. (2013) 'Refugee Law, Gender and the Concept of Personhood', International Journal of Refugee Law 25 (3), pp. 470-501.

Fotopoulou, A. (2012) 'Intersectionality Queer Studies and Hybridity: Methodological Frameworks for Social Research', Journal of International Women's Studies 13(2), pp. 1932.

Giametta, C. (2014) 'Rescued' subjects: The question of religiosity for non-heteronormative asylum seekers in the UK, Sexualities 17(5/6), pp. 583-599

Haraway, D. (1991): "Situated Knowledges: The Science Question in Feminism and the Privilege of Partial Perspective", Feminist Studies, 14, pp. 575-599.

Held, N. (2016) "What does a 'genuine lesbian' look like? Intersections of sexuality and 'race' in Manchester's Gay Village and in the UK asylum system." In: Stella, Francesca, Taylor, Yvette, Reynolds, Tracey and Rogers, Antoine (eds.) Sexuality, citizenship and 
belonging: trans-national and intersectional perspectives. Routledge: London, pp. 131148.

Herlihy, J., Kate G. and Turner, S. (2010) 'What Assumptions About Human Behaviour Underlie Asylum Judgements?', International Journal of Refugee Law 22 (3), pp. 351-366.

Hübner, K. (2016) 'Fluchtgrund sexuelle Orientierung und Geschlechtsidentität: Auswirkungen von heteronormativem Wissen auf die Asylverfahren LGBTI-Geflüchteter', Feministische Studien 16 (2), pp. 242-260.

Johnson, T. (2011) 'On Silence, Sexuality and Skeletons: Reconceptualizing Narrative in Asylum Hearings', Social and Legal Studies 20(1), pp. 57-78.

Johnson-Bailey, J. (1999) 'The ties that bind and the shackles that separate: race, gender, class, and color in a research process', Qualitative Studies in Education, 12 (6), pp. 659670.

Lacroix, M. (2004) 'Canadian Refugee Policy and the Social Construction of the Refugee Claimant Subjectivity: Understanding Refugeeness', Journal of Refugee Studies 17 (2), pp. 147-166.

Lee, O.J. and Brotman, S. (2011) 'Identity, Refugeeness, Belonging: Experiences of Sexual Minority Refugees in Canada', Canadian Review of Sociology, 48 (3), pp. 241-274.

Lewis, R.A. (2014) '“Gay? Prove it”: The politics of queer anti-deportation activism', Sexualities Vol. 17(8) 958-975. 
Lorde, A. (1984a) Sister Outsider. Essays and Speeches. Trumansberg and New York: Crossing.

Lorde, A. (1984b) Zami: A New Spelling of My Name. London: Sheba Feminist Publishers.

McCarthy, K. (2012) An exploration of the experience of refugee and asylum seeking people in higher and further education and their strategies for managing the challenges encountered. MA in Sociology and Global Change research project. Unpublished.

McCarthy, K. (2015) What is the experience of lesbian asylum seekers of living their sexuality in their home countries and in the UK? MA Dissertation. Unpublished.

McKinnon, C. (2013) 'Intersectionality as method: a note', Signs: Journal of Women in Culture and Society 38 (4), pp. 1019-1030.

Micro Rainbow International (MRI) (2013) Poverty, Sexual orientation and Refugees in the UK. London. Available at: https://www.micro-rainbow.org/wpcontent/uploads/MR REPORT UK digital-final-for-the-web-Reduced.pdf, access date 01.02.2017.

Middelkoop, L. (2013) Chapter 1 in Spijkerboer, T Fleeing homophobia: sexual orientation, gender identity and asylum. London: Routledge.

Millbank, J. (2013) Chapter 2 in Spijkerboer, T Fleeing homophobia: sexual orientation, gender identity and asylum London: Routledge. 
Morgan, D. (2006) 'Not Gay Enough for the Government: Racial and Sexual Stereotypes in Sexual Orientation Asylum Cases', Law \& Sexuality: A Review of Lesbian, Gay, Bisexual, and Transgender Legal Issues 15, pp. 135-162.

Nayak, S. (2015) Race, Gender and the Activism of Black Feminist Theory: Working with Audre Lorde. Hove: Routledge.

O'Leary, B. (2008) '"We Cannot Claim any particular Knowledge of the Ways of Homosexuals, Still Less of Iranian Homosexuals...": The particular Problems Facing Those who seek Asylum on the Basis of their Sexual Identity.' Feminist Legal Studies 16 (1), pp. 87-95.

Shidlo, A and Ahola, J. (2013) 'Mental health challenges of LGBT forced migrants', Forced Migration Review 42, pp. 9-11.

Smith, J.A., Flowers, P. \& Larkin, M. (2009) Interpretative Phenomenological Analysis: Theory, Method and Research, London: Sage Publications Ltd.

Spijkerboer, T. and Jansen, S. (2011) Fleeing Homophobia: Asylum Claims Related to Sexual Orientation and Gender Identity in the EU. VU University: Amsterdam.

Stonewall (2012) Mental health. Available at:

http://www.stonewall.org.uk/sites/default/files/Mental Health Stonewall Health Briefing 2012.pdf Accessed 29/01/2017 
UK Lesbian and Gay Immigration Group (UKLGIG) (2010) Failing the Grade. UKLGIG:

London. Available at http://uklgig.org.uk/wp-content/uploads/2014/04/Failing-the-

Grade.pdf, access date: 08/04/2015.

UK Lesbian and Gay Immigration Group (UKLGIG) (2013) Missing the Grade. UKLGIG:

London. Available at http://www.uklgig.org.uk/wp-content/uploads/2014/02/Missing-theMark.pdf, access date: 08/04/2015.

Vervliet, M., De Mol, J., Broekaert, E., Derluyn. I. (2014) “'That I Live, that's Because of Her": Intersectionality as Framework for Unaccompanied Refugee Mothers', British Journal of Social Work 44, pp. 2023-2041.

Weeks, J. Holland, J. Waites, M. (2002) Sexualities and Society: a reader. Oxford: Polity.

Yuval-Davis, N. (2011) The politics of belonging: intersectional contestations. London: Sage. 